were identical to those of the reference compounds. The methyl esters were detected by reagents $b, c$, and $d$, the dilactones by reagent $d$.

Reduction. An aliquot of the esterification product $(20 \mathrm{mg})$ was reduced with lithium aluminium hydride $(0.3 \mathrm{~g})$ in tetrahydrofuran $(30 \mathrm{ml})$ by gentle reflux for $2 \mathrm{~h}$. The reaction product $(13 \mathrm{mg})$ furnished an alcohol, indistinguishable from $\mathrm{D}$-glucitol by chromatographio investigation in the solvent systems $A, B$, and $D$. The alcohol was detected by reagent $c$.

De-O-methylation ${ }^{10}$ failed to cause a change in chromatographic mobility of the alcohol.

Acknowledgements. The authors are greatly indebted to the head of the Department of Pharmacognosy, Professor Arnold Nordal, for his interest in this work and for his valuable support. Financial support was rendered to one of the authors (M.A.) by Norges Almenvitenskapelige Forskningsråd.

1. Nordal, A. Medd. Norsk Farm. Selskap 8 (1943) 129.

2. Bernatek, E., Nordal, A. and Ogner, G. Acta Chem. Scand. 17 (1963) 2375.

3. Bøe, J. E., Winsnes, R., Nordal, A. and Bernatek, E. Acta Chem. Scand. 23 (1969) 3609.

4. Gorter, K. Rec. Trav. Chim. 31 (1912) 281.

5. Kessler, G., Neufeld, E. F., Feingold, D. S. and Hassid, W. Z. J. Biol. Chem. 236 (1961) 308.

6. Smith, F. J. Chem. Soc. 1944633.

7. Abdel-Akher, M. and Smith, F. J. Am. Chem. Soc. 73 (1951) 5859.

8. Gordon, H. T., Thornburg, W. and Werum, L. N. Anal. Chem. 28 (1956) 849.

9. Trevelyan, W. E., Procter, D. P. and Harrison, J. S. Nature 166 (1950) 444.

10. Bonner, T. G., Bourne, E. J. and McNally, S. J. Chem. Soc. 19602929.

Received October 3, 1970.

\section{N-Quarternary Compounds}

\author{
Part XX. ${ }^{1}$ Stereochemical Studies
}

KJELL UNDHEIM and TYGE GREIBROKK Department of Chemistry, University of Oslo,
Oslo 3, Norway

$\mathrm{O}$ ur stereochemical studies ${ }^{2,3}$ in the dihydrothiazolo[3,2-a]pyridinium-8-oxide series required the establishment of relative configuration by $\mathrm{X}$-ray analysis. For this purpose we have synthesized a bromosulphoxide (VI).

The product obtained by the addition of the thiolactam (I) to $\alpha$-bromoisocrotonic acid followed by cyclisation of the adduct over the annular nitrogen has been assigned a trans configuration on the basis of the value of the coupling constant, $J_{2,3}<1$, in the NMR spectrum in TFA. ${ }^{2}$ The trans configuration has now been confirmed by X-ray analysis of VI.

Peracid oxidation of the thioether (III) gave the diastereomeric sulphoxides in the ratio 9:1. The stereoselectivity in the oxidation was further increased by having a trans methyl group in the 2-position (IV). In agreement with NMR arguments ${ }^{8}$ cis oxidation of the sulphur with respect to the carboxy group was assumed. For this assumption to be correct the carboxy group must participate in the oxidation. The mechanism proposed is either a rapid, preferential oxidation of the carboxy group, the formation of a diacylperoxide intermediate, or the formation of a hydrogen bonded complex between the peracid and the carboxy group. The actual species involved should depend on the experimental conditions. X-Ray analysis of VI confirms that the sulphinyl oxygen is cis with respect to the carboxy group."

The sulphoxides are very readily decarboxylated. We have used this in the preparation of optically active sulphoxides of type VIII. Thus oxidation of compound III with the $I_{\text {- }}$-configuration followed by decarboxylation led to an optically active sulphoxide essigned the absolute $S$-configuration..$^{3}$ From the discussion above it follows that this assignment is in agreement with the relative stereochemistry of VI determined by X-ray analysis. ${ }^{4}$

The sulphoxide (VI) is formulated as a phenolate rather than as a carboxylate since the X-ray analysis" shows strong 
<smiles>[R]/C=C(/Br)C(=O)O</smiles><smiles></smiles>

VIII<smiles></smiles>

III $\mathrm{R}=\mathrm{H}$ IV $\mathrm{R}=\mathrm{CH}_{3}$<smiles>Cc1ccc([O-])c2c1[Si](=O)[C@@H]([C@H](C)O)[C@H]2C(=O)O</smiles>

VIII<smiles></smiles><smiles></smiles>

घ hydrogen bonding between the phenolic oxygen and a carboxyl oxygen, the distance between the oxygens being $2.46 \AA$, with the hydrogen closer to the carboxyl oxygen.

The synthesis of VI is outlined above. Compound IV was synthesized as previously described ' and was brominated using bromine in acetic acid. Electrophilic substitution in 5-methyldihydrothiazolo[3,2-a]pyridinium-8-oxide systems have been shown by chemical means to take place in the 7-position." The X-ray work confirms that the bromine has entered the 7-position. The oxidation of $V$ was carried out in formic acid by the addition of hydrogen peroxide. Chromatography showed that only traces of the trans sulphoxide was formed, the major product having the cis configuration.

Experimental. 7-Bromo-trans-2,5-dimethyl-8hydroxydihydrothiazolo[3,2-a]pyridinium-3-carboxylate $(V)$. Bromine $(3.2 \mathrm{~g}, 0.02 \mathrm{~mol})$ in acetio acid ( $100 \mathrm{ml}$ ) was added dropwise over $2 \mathrm{~h}$ to a solution at $50^{\circ}$ of trans-2,5-dimethyl-8-hydroxydihydrothiazolo [3,2-a] pyridinium -3 -car boxylate $^{2}(4.0 \mathrm{~g}, 0.016 \mathrm{~mol})$ and sodium acetate $(2.0 \mathrm{~g}, 0.02 \mathrm{~mol})$ in acetic acid $(400 \mathrm{ml})$. The solution was left at room temperature and the precipitated bromo-hydrobromide $(6.5 \mathrm{~g})$ collooted. The base was liberated by dissolution in water and passage through a DEAE Sephadex A-25-oolumn. After washing the column with water the base was eluted with $0.05 \mathrm{~N}$ formic acid. Evaporation of the eluate yielded the bromo compound (4.4 $\mathrm{g}, 83 \%$ ), m.p. $180^{\circ}$ (dec.). The analytical sample was recrystallized from water. (Found: C 39.60; $\mathrm{H}$ 3.56; $\mathrm{N}$ 4.90. Calo. for $\mathrm{C}_{10} \mathrm{H}_{10} \mathrm{BrNO}_{3} \mathrm{~S}$ : C 39.43; H 3.29; $\mathrm{N}$ 4.61.)
7-Bromo-3-carboxy-trans-2,5-dimethyl-1-oxodihydrothiazolo [3,2-a]-pyridinium-8-oxide (VI). $30 \%$ Hydrogen peroxide (1 ml, $0.012 \mathrm{~mol}$ ) was added dropwise at $0^{\circ}$ to a solution of 7 bromo -trans -2,5 -dimethyl -8 -hydroxydihydrothiazolo[3,2-a]pyridinium-3-carboxylate $(1.0 \mathrm{~g}$, $0.003 \mathrm{~mol})$ in formic acid $(80 \mathrm{ml})$. The solution was left at $5^{\circ}$ for $3 \mathrm{~h}$, the solution evaporated at reduced pressure and the residue dissolved in cold water $(7 \mathrm{ml})$. The major sulphoxide isomer crystallized out on standing at $5^{\circ}$ overnight, yield $0.8 \mathrm{~g}(76 \%)$. This compound is very susceptible to decarboxylation and gave no sharp melting point on heating.

Chromatography ${ }^{3}$ of the reaction mixture before isolation showed that the sulphoxide formed consisted of $90-95 \%$ of the one stereoisomer.

The analytical specimen was prepared by dissolving the product in warm formic acid $(2 \mathrm{ml})$ followed by the addition of water $(10 \mathrm{ml})$ and leaving the solution in the cold when the sulphoxide orystallized out. (Found: C 37.64; $\mathbf{H}$ 3.43; $\mathrm{Br} 25.40 ; \mathrm{N}$ 4.53. Calc. for $\mathrm{C}_{10} \mathrm{H}_{10} \mathrm{BrNO}_{4} \mathrm{~S}$ : C 37.47; H 3.13; Br 25.00; N 4.37.)

1. Undheim, K. and Grønneberg, T. Acta Chem. Scand. 25 (1971). In press. (Part XIX.)

2. Undheim, K. and Borka, L. Acta Chem. Scand. 23 (1969) 1715.

3. Undheim, K. and Nordal, V. Acta Chem. Scand. 23 (1969) 1966.

4. Personal communication from Niels Thorup, Danmarks Tekniske Højskole, Lyngby, Denmark.

5. Undheim, K. and Nordal, V. Acta Chem. Scand. 23 (1969) 1975.

Received November 6, 1970.

Acta Chem. Scand. 24 (1970) No. 9 